\title{
Corporal and Cognizant Barriers to Voting: the Impact of COVID-19 on the 2020 Election Season in St. Louis
}

\author{
Gary Parker ${ }^{1,2} \oplus \cdot$ Ellen Hutti ${ }^{2}$
}

Accepted: 5 December 2021 / Published online: 15 January 2022

(c) The Author(s), under exclusive licence to Springer Nature Switzerland AG 2021

\begin{abstract}
In 2020, two key elections in St. Louis, Missouri, took place in the midst of the intertwined pandemics of COVID-19 and racialized violence. Local community leaders in St. Louis emphasized a need to mobilize voters, particularly in communities of color, to engage in the elections in August and November 2020 as a tool for advancing health and racial equity. COVID-19 created a new set of barriers to voting. This study documents two typologies of challenges that organizers faced in their efforts to mobilize voters and increase participation in the election. The first is corporal - the use of one's physical body and the risk within. The second is cognizant the regulatory proficiency needed to navigate the shifting rules of the voting process. In this study, semi-structured interviews were conducted with a purposive sample of twenty-eight mobilizers working within low-income, poverty-impacted neighborhoods in St. Louis City and St. Louis County, which disproportionately consist of residents of color. Findings suggest COVID-19 created additional unforeseen barriers to voting. Corporal: Local ordinances that mandated limited in person gatherings and social distancing were serious obstacles to traditional voter mobilization efforts and created trepidation about in-person voting for fear of being exposed to the virus. Cognizant: The state of Missouri in an effort to address some of the public health concerns created additional rules for absentee or mail-in voting for limited populations with a complicated set of rules that confused mobilizers and voters.
\end{abstract}

Keywords COVID-19 - Voting · Get-out-the-vote $\cdot$ Elections $\cdot$ Health politics $\cdot$ Racial inequality $\cdot$ St. Louis $\cdot$ Missouri

Gary Parker

gary.parker@wustl.edu

1 Hebrew University of Jerusalem, Jerusalem, Israel

2 Clark-Fox Policy Institute Brown School, Washington University in St. Louis, One Brookings Drive, Campus, Box 1196, St. Louis, MO 63130, USA 


\section{Introduction: Two Elections and Two Pandemics}

In 2020, two critically important elections took place in Missouri. The first, held in August, put before voters an amendment to the Missouri Constitution that would expand Medicaid eligibility. At the time, Missouri was one of only thirteen states that had not adopted the Affordable Care Act (Huang et al., 2020). The second election in November would determine the next President of the USA.

During the 2020 election season, the country was also in the midst of two pandemics: COVID-19 and racialized violence. As the number of pandemic-related hospitalizations and fatalities grew, those without health insurance were increasingly vulnerable to medical debt and bankruptcies (Gaffney et al., 2020). The COVID-19 pandemic was disproportionately affecting communities of color and elders, and highlighting the health and economic disparities that were long-standing within those communities. Because of the consequences of the pandemic, there was a heightened awareness of the need for access to affordable healthcare (Allen \& Sommers, 2020; Gruber \& Sommers, 2020).

Furthermore, increased attention was brought to the movement for racial justice when George Floyd, a Black man in Minneapolis, died when a white law enforcement officer kneeled on Floyd's neck for $8 \mathrm{~min}$ and $46 \mathrm{~s}$. This once again elevated the brutality experienced by Black Americans when interacting with police (Barbot, 2020; Barrie, 2020). Protests organized by leaders of Black Lives Matter took place across the country with tens of thousands of participants chanting, "I can't breathe," which George Floyd had repeated while pinned by police (Oriola \& Knight, 2020). The large protests were held despite the potential for the gatherings to become super spreader events of COVID-19 (Valentine et al., 2020).

St. Louis has a similar history of racial violence perpetuated by law enforcement (Schwartz \& Jahn, 2020). In August 2014, a white police officer fired twelve bullets directed at a Black teenager. Six bullets hit the intended target resulting in the death of Michael Brown, Jr. Following the deadly shooting, protests erupted drawing attention to racial tensions between police and local residents in Ferguson, a small suburb of St. Louis, Missouri. The incident sparked a deeper discourse around the history of racism and inequality in St. Louis and the need for transformative policies that would create a more just and equitable society (Davey, 2017). After the death of Michael Brown, Jr. on Aug. 9, 2014, "Ferguson" came to symbolize racial strife and inequality in the USA (Ferguson Commission, n.d.; Hudson et al., 2020).

As a result of the intertwined pandemics, local community leaders in St. Louis City and St. Louis County ${ }^{1}$ emphasized a need for voters, particularly in communities of color, to engage in the elections in August and November 2020 as a tool for advancing health and racial equity. However, the circumstances surrounding the COVID-19 pandemic in particular created new challenges to connecting with eligible voters, and for voters to engage in the electoral process. These challenges can be divided into two typologies. The first is corporal - the use of one's physical body

\footnotetext{
1 St. Louis City and St. Louis County are two separate counties that make up the greater St. Louis area in Missouri.
} 
and its potential risk. The second is cognizant - the regulatory proficiency needed to navigate the shifting rules of the voting process.

Engaging in the democratic process presented corporal risk that was higher within communities of color. As COVID-19 spread across the USA, communities of color were disproportionately impacted and more likely to contract and die from the disease. This was the result of generations of social and economic inequities that undermine the health and mental health of populations of color (Cooper \& Williams, 2020; Fortuna, 2020). Furthermore, workers of color tend to be low wage earners in "essential" positions that require close proximity to the public, thereby increasing their potential exposure to the virus. Limited access to personal protective equipment (PPE) compounded the risk (Pangborn \& Rea, 2020; The Lancet, 2020). Data released by the St. Louis Metropolitan Pandemic Task Force in June 2020 demonstrated that although less than one-fifth of the population was Black, almost $50 \%$ of all COVID-related mortalities were Black patients (Garza, 2020). It is not just underlying health conditions that put populations of color at elevated risk; it is a host of factors related to institutional racism - the historic policies and systems that foster racial discrimination, including access to quality healthcare (Gee \& Ford, 2011; Majette, 2003).

Little is known about how fear of the virus played into the decision making process of community mobilizers and potential voters on whether or not they would participate in the 2020 elections. However, previous research suggests that poor health is related to lower voter turnout. In multiple studies, those with self-rated poor health were consistently less likely to vote compared to those with good, very good, or excellent health (Gollust \& Rahn, 2015; Mattila et al., 2013; Pacheco \& Fletcher, 2015). While the impact of poor health on voting behavior persists across age groups, the effect of this finding increases with age (Mattila et al., 2013; Pacheco \& Fletcher, 2015). Other research into chronic conditions has revealed a more nuanced impact of health on voting. One study found that those with cancer were more likely to vote, whereas those with heart disease, lower emotional support, disabilities, and those without insurance were less likely to vote (Gollust \& Rahn, 2015).

Voters need the knowledge and confidence to maneuver through the cognizant challenges of voting, and the pandemic was further complicating the process. The US Constitution grants citizens the right to vote. However, it allows the states the ability to regulate "times, places and manner of holding elections" (The Constitution of the United States, 2015). Procedural burdens and shifting regulations have historically been created in order to disenfranchise voters. Complicated registration processes, poll taxes, literacy tests, and more have successfully served as barriers to voting by citizens of color (Ellis, 2008; Keyssar, 2009).

In a stated effort to reduce the potential exposure to COVID-19, the state of Missouri implemented some temporary changes to the process of voting. The existing law dictated that eligible voters meeting certain criteria are able to request an absentee ballot that could returned by mail or in person to the respective county's Board of Elections. Absentee voters were required to present a government issued identification and some, but not all, were required to have their ballots notarized. For example, if you were active military or disabled, you did not need to notarize your ballot. However, if you were incarcerated or out of the election district on Election 
Day, notarization was required. It is important to note that concern of contracting COVID-19 by voting in person was not a qualifying reason to receive an absentee ballot.

In response to the limitation of absentee ballots, the state of Missouri passed legislation temporarily allowing for mail-in ballots. All mail-in ballots were required to be notarized. Additionally, mail in ballots had to be mailed and could not be returned in person. Voting rights groups filed lawsuits challenging several parts of the new law arguing that "Missourians who seek to vote by mail this fall will face a confusing and burdensome regime that will result in widespread, unavoidable, and unconstitutional chaos and disenfranchisement" (American Women's Petition for Declaratory and Injunctive Relief, 2020, p. 3). The court ultimately let the current ballot and notary rules stand (Appeal from the Circuit Court of Cole County, 2020). Ultimately, the confusion caused by the new rules and the legal challenges created a new set of cognizant barriers to voter engagement.

There are consequences for any decline in democratic participation, particularly by people with lower socio-economic status. Low voter turnout among povertyimpacted voters contributes to the ongoing existence of government policies and funding decisions that have negatively impacted those experiencing poverty and are people of color (Day \& Schiele, 2012; Hacker \& Pierson, 2010). "Low-income voters are much less likely to vote or to be politically knowledgeable than high-income voters, which limits their influence and creates an upper-income bias to effective public opinion" (Erikson, 2015, p. 11).

\section{The Theories of Protection Motivation and Political Efficacy}

Two theoretical constructs underpin this research: the theory of protection motivation and the theory of political efficacy. Protection motivation theory (PMT) is a cognitive model of behavior used to understand the response to perceived physical threats and describes the challenges of overcoming the corporal risks to voting during a global pandemic. The theory consists of four factors: an appraisal of the threat, the perceived vulnerability to the threat, the effectiveness of risk preventative behavior, and the ability to engage in the preventative behavior (Floyd et al., 2000; Milne et al., 2000).

This theory has been applied in numerous studies seeking to understand the decisions of various populations impacted by COVID-19, including health care providers, tourists, consumers, employees in the workplace, and vaccine recipients (AlRasheed, 2020; Hsieh et al., 2021; Lin et al., 2021; Rather, 2021; Youn et al., 2021). Organizers engaged in mobilization, as well as the voters, had to evaluate the overall threat of COVID-19, their particular vulnerability to the virus, if there were preventative measures that were effective, and then decide if they had the ability to adhere to those measures.

During an election cycle, community organizers engaged in voter mobilization efforts focused on overcoming the cognizant challenges to voting by increasing the political efficacy of citizens. The theory of political efficacy reasons that in order for a citizen to vote, they must have confidence that they have a firm understanding 
of political issues (internal efficacy) and that the government will respond to their vote accordingly (external efficacy) (Anderson, 2010; Beaumont, 2010; Niemi et al., 1991; Pollock, 1983). If either of these beliefs is missing, the likelihood of participation is greatly diminished (Craig, 1979; Jung et al., 2011; Morrell, 2005). Citizens with higher levels of political efficacy are more likely to vote that those with lower levels (Karp \& Banducci, 2008; McDonnell, 2019; Rosenstone \& Hansen, 1993).

Internal political efficacy is defined as the confidence a citizen has in their knowledge about politics and policy. The theory posits that with higher levels of internal political efficacy, citizens are more confident in their ability to advance their selfinterests, and the decisions they make at the ballot box will accurately reflect their values and political goals. Conversely, those with lower levels of internal political efficacy are less knowledgeable about political issues and are uncertain about making an informed decision (Morrell, 2005; Reichert, 2016).

External political efficacy refers to the extent a citizen has confidence that the government will respond to the demands of its citizens (Abramson \& Aldrich, 1982). This requires a certain level of political trust, which reflects "people's attitudes toward the functioning of government" (C. J. Anderson \& LoTempio, 2002, p. 336).

The ultimate goal for GOTV mobilizers is for citizens to feel they are competent on pressing policy issues and that government can and will respond to the will of the people. The interventions they employ are voter education, providing contact with candidates, voter registration drives, and countless other tactics and strategies. This can be challenging due to structural barriers that have existed for generations that have led to an increase in disenfranchised voters.

Through key informant interviews, this paper will document the perceived ways in which GOTV mobilizers were facing new barriers that discouraged and prevented electoral engagement by poverty-impacted populations and voters of color. Time and resources were limited, and these leaders were attempting to maximize the impact of GOTV initiatives while in the midst of a global pandemic. An increase in turnout has the ability to shift public resources to address unmet community needs particularly in the areas of healthcare and racial justice.

\section{Methods}

\section{Setting}

The collection of data occurred between April 2020 and January 2021 and reflects the experiences of mobilizers during the November 2020 election. As the data collection began, St. Louis City and St. Louis County issued public health protocols in response to the COVID-19 pandemic that would minimize the spread of the disease. Although originally intended to be in-person, semi-structured interviews were conducted and recorded via Zoom, a video conferencing platform. Zoom allowed for face-to-face connection, as well as the ability to maintain mandated public health orders (Gray et al., 2020; Public Health Orders, n.d.). To ensure confidentiality of 
the subjects, a virtual private network (VPN) was used ensuring a secure encrypted connection. Additionally, each subject was given a unique Zoom link so that no one would be able to join a call in progress.

\section{Participants}

A combination of criterion and chain sampling was utilized to identify GOTV leaders engaged in mobilization efforts focused on promoting individual candidates, voter referendums, and/or nonpartisan voter registration/information efforts within poverty impacted neighborhoods of St. Louis City and St. Louis County (Palinkas et al., 2015). This sampling strategy allowed for research subjects to be informationrich, facilitating an in-depth study (Gentles et al., 2015; van Manen, 2016). Participants were eligible for this study if they (1) are/have been engaged in a GOTV efforts, (2) are/have been in a leadership/decision making role in the initiative, and (3) are/have been aimed specifically at mobilizing eligible voters in povertyimpacted communities in greater Saint Louis.

\section{Data Collection}

Semi-structured interviews lasting 45-75 min were conducted with leaders engaged in GOTV efforts. The semi-structured format allowed for flexibility in the data collection (Kallio et al., 2016). To understand the experiences of those working on the frontlines of voter mobilization, key themes informed by the theoretical framework were explored: GOTV strategies, resource allocation, voter engagement/apathy, barriers to voting, and political efficacy. More specifically, questions included the following: What are some of the challenges you are facing as a result of COVID-19? In what ways has your approach to mobilization changed? How are you protecting your health and safety?.

Identifying and interviewing research subjects continued until there was a clear demonstration of saturation and redundancy (Guest et al., 2006; Hennink et al., 2017). The semi-structured format allowed for flexibility in the data collection and facilitated the ability to explore the impact of the pandemic on the ability to mobilize voters (Kallio et al., 2016). The transcriptions were individually reviewed for accuracy and de-identified by the research team.

\section{Ethical Considerations}

This research was a collaboration between Hebrew University in Jerusalem and Washington University in St. Louis. Prior to any contact with research subjects, the Washington University Institutional Review Board approved all research protocols (IRB \# 202,001,167). At the start of each interview, participants were briefed on the project, informed the recording was confidential and would be shared with the research team, and given the opportunity to voice questions or concerns. 


\section{Data Analysis}

A thematic analysis utilizing both a deductive and inductive approach was used. Codes were predefined based on the literature, theoretical framework, and the research questions. As the data were analyzed, additional codes emerged, and the codebook was adapted as needed. The final codebook contained 23 codes. Two researchers coded the full data set using NVivo, which facilitated collaboration among the research team (Wong, 2008). Discrepancies were minor, and the researchers met regularly to discuss and resolve them. From the coded data, substantive themes and subthemes were developed as patterns emerged. A thematic analysis was conducted using the constant comparative method in the grounded theory approach (Kolb, 2012).

\section{Results}

Fifty-three mobilizers were approached. Twenty-one did not respond after two requests. Four responded, agreed to be interviewed, and did not respond to scheduling requests. Twenty-eight community mobilizers responded and were interviewed for this study. Nineteen identified as female, and nine identified as male. Eight subjects identified as Black, one as Hispanic, and nineteen as white. Twelve were mobilizing for a specific ballot initiative. Four were working for candidates for elected office. Nine solely focused on nonpartisan voter registration and information campaigns. Three were working on issue campaigns and well as for candidates.

\section{Discussion}

COVID-19 created additional unforeseen corporal barriers to voting. Mobilizers needed to ensure that they were protecting their health and the health of the voters they contacted. Furthermore, the leaders of St. Louis City and St. Louis County issued local ordinances that mandated limited in person gatherings and social distancing. The measures taken on a personal and governmental level aimed at protecting the physical wellbeing of local citizens presented serious obstacles to traditional voter mobilization efforts and created trepidation about in-person voting for fear of being exposed to the virus.

In response to the pandemic, the state of Missouri created new rules for absentee or mail-in voting for limited populations with a complicated set of rules. Understanding how to navigate through the rules in order to vote and have the vote deemed valid created a cognizant challenge that is compounded by existing structural barriers that dissuade eligible voters. Voter identification laws, polling sites that are not easily accessible, limited in-person and early voting, lack of 
same-day voter registration, the purging of registered voter lists, ballots available only in English, and other obstacles hindered the ability to engage in the democratic process.

\section{Corporal Challenges}

Community organizers engaged in voter mobilization faced new challenges during the COVID-19 pandemic. In March 2020, mandatory stay-at-home orders were issued by the St. Louis Mayor and St. Louis County Executive in an effort to protect the health of residents and slow the spread of the coronavirus (Associated Press, 2020). Additionally, organizers had to access their level of vulnerability to the virus and how they may protect themselves and others. This is aligned with the theory of protection motivation as the pandemic was appraised as a threat to the general population. Following the cognitive model, since there was uncertainty around transmission as well as the knowledge of and effectiveness preventative behavior, mobilizers struggled to navigate new barriers to voter engagement.

Public events were cancelled, and opportunities to meet with large numbers of residents no longer existed. This prevented mobilizers from attending festivals, concerts, street fairs, and other outdoor events that were often the setting for petitioning for voter referendums, voter registration drives, and campaigning for candidates and ballot initiatives. One campaign consultant offered,

We can't go stand outside of stores trying [to] have petitions there, if you're doing signature collection. We can't have fundraisers in person. We can't make a campaign video with a crowd of people to show all of our support. I think people are struggling to figure out how to do those things in ways that are also responsive to what's going on. (Subject 1).

It also prevented canvassing from door-to-door while the ordinances were in place through mid-May. This prevented candidates from visiting the homes of voters in their district. The opportunity for candidates to build relationships with voters by meeting them face-to-face was diminished. One organizer offered, "Yeah, what we know how to do is knock on the door and talk to someone on their porch. And as organizers, you really believe that back and forth is important" (Subject 4). Additionally, many organizations were concerned about the safety of workers and volunteers. "We can't go to the doors. This year, my organization, my board voted against that. They didn't want anybody bring any lawsuits or us having to sign waivers or anything and I appreciate that" (Subject 7).

Recent studies have confirmed that individuals over the age of 60 are at higher risk for contracting the virus (Bassett et al., 2020; Bhopal \& Bhopal, 2020). Many election judges and poll workers are elders. Polling sites had to be consolidated since the number of poll workers and election judges dropped, as many seniors did not want to risk being exposed to the virus on Election Day. "The thing that I'm really worried about is actually election judges and closing polling places because there are not enough election judges. I think the average age of an election judge in Missouri, I believe, is 71" (Subject 9).

In previous elections, many polling sites were located in senior housing and health facilities. In another effort to protect the elder population, polling places were 
relocated so that the general public would not pass through resident facilities. The relocation of polling sites is not new: "Basically every election the polling places that you're supposed to go to seem to change, especially in areas where population is more fluid, which makes it hard to vote" (Subject 5). However, the number of sites that were changed and/or eliminated was reported to have reached new heights, "half the number of polling locations are open. What is that going to look like in terms of lines? Waiting to vote. I mean, you can't be huddled together going into a building in November. Most people are going to be outdoors waiting because you can't be close together. Do you stand there and wait? Do you walk away?" (Subject 11).

Closing and relocating poll sites have shown to reduce voter turnout (Brady \& McNulty, 2011). The COVID-19 pandemic resulted in a large drop in the number of poll workers during a primary election in Wisconsin, causing officials to consolidate polling places in response. In Milwaukee, the number of polling places shrank 97\% from 182 locations in November 2016 to just five in 2020. These polling place closures were found to have decreased overall voter turnout in Milwaukee by 8.7 points and Black voter turnout by 10 points (Morris \& Miller, 2020).

Transportation to polling sites is also another long-standing issue, particularly in low-income neighborhoods that have limited access to public transportation. In pre-pandemic elections, mobilizers organized volunteers to drive voters to the polls. COVID-19 presented health safety issues to these programs, "We didn't want to do the rides to the polls because you have to get in the car with someone and we didn't want to expose our volunteers or the voters to getting sick" (Subject 24).

\section{Cognizant Challenges}

Mobilizers regularly grapple with identifying effective approaches to increasing the political efficacy of voters. The pandemic introduced additional obstacles to improving efficacy. Changes in the rules and the lawsuits created confusion among voters and mobilizers alike. Not only do they need to understand the political issues and trust the government will respond, they now need to know how to navigate a mutable political process.

"I mean, ourstate's absentee process was despicable. It was confusing, it was alwayschanging. I mean, it was hard communicating to voters" (Subject 21).

"We just didn'tknow what the rules were going to be. And it was really difficult" (Subject 18)."We tracked what was happening at the pollsand found that people working the polls didn't even really know the rules"(Subject 3).

If a voter was able to determine that they qualified to participate via absentee or mail-in ballot, a kaleidoscope of rules and regulations must be followed or the ballot would be invalidated. First, depending on the reason for voting absentee, a notary may be required. A voter must find a notary and bring their ballot to them in person.

(Absentee and mail-in ballots)... require a notary public to notarize your application, which makes one more step. Then in the case of COVID-19 and the pandemic, you're supposed to be isolated, where am I going to find them? I'm not a notary. I mean, I would have to go to a notary in order to get a notarization. (Subject 2). 
The next hurdle in the process is to mail the ballot early enough that it arrives by Election Day. The law required mail-in ballots to be mailed by the US Postal Service and prohibited returning the ballot in person. One mobilizer explained, "In Missouri the ballot has to be received by Election Day and not post marked by Election Day...Most people don't know that if you just use the prepaid postage that it comes with, well that's actually third class mail, not first class mail. So, it could take several days to get there" (Subject 9).

Even if a voter qualified for absentee/mail-in voting, had their ballot notarized, and mailed it early enough so that it arrives by Election Day, their vote still might not be counted. If the form is not filled out with complete accuracy, it is discarded. Furthermore, the Board of Elections is not required to inform the voter that their ballot has been invalidated.

There's ...no legal obligation to contact people whose ballots are being rejected. And they don't record that anywhere in the voter file, either. So, if I called up and said, "Was my ballot rejected in 2018?" All they would say, "We just have on record that you didn't vote in 2018." So, they don't they don't say that it was rejected. They don't say why. It's on the ballot itself in some storage facility, but it's never connected with the voter file. (Subject 13).

Voters from low-income and poverty-impacted neighborhoods, as well as senior citizens, are particularly vulnerable.

There's a lot of negatives to mail-in voting because especially low-income communities and communities of color had their ballots rejected at a higher rate than others because you have to fill it out. Exactly. Check every box, cross every, was it dot every "I," cross every "T" whatever it is. And if any one of those things isn't done, your whole ballot is rejected. (Subject 19).

Many senior citizens who had taken advantage of the absentee ballot because of COVID and ... failed to follow some of the directions on the back envelope... their ballot was going to be rejected. (Subject 23).

The confusion around who qualified for absentee and mail-in ballots, what needed notarizing, how to return the ballots, and the increased potential for votes to be invalidated have created a new barrier to voting. The complex rules discourage voters. "I think Missouri's convoluted absentee process and mail-in process ... is designed to be confusing and designed in a way that those votes actually don't count. So, that is a problem. That turns off voters. I mean, I just think it is hard" (Subject 10).

Many of the organizers saw the new rules as evidence of the continued effort to disenfranchise voters on the basis of race and socio-economic status. It was means to lower political efficacy and reduce voter turnout. One organizer said, "I'd say it's ... systemic racism and the lack of access to resources and information. And because of all of that, you can't really blame people for not feeling like it matters what they think and not voting because of it" (Subject 15).

Although COVID-19 presents a unique set of factors, the elaborate set of rules that have been created in response will not completely dissipate when the immediacy of the pandemic subsides. Mobilizers will continue to struggle with systems seemingly designed specifically to reduce the political efficacy of voters. 


\section{Conclusion}

Since the founding of the democratic process in the USA, structural barriers have been in place that contributed to generations of disenfranchised voters. This study demonstrates the corporal and cognizant challenges that community organizers faced as a result of the health dangers caused by COVID-19. Furthermore, the complicated response by the State of Missouri created new barriers with an implementation of a set of rules that confused voters. Future research that quantifies the number of ballots that were disqualified for any reason and examines which populations were most impacted would demonstrate the true impact of shifting and multiplying rules and how they may have affected the results of the 2020 election season.

This study may be the first to gather qualitative data examining the impact of COVID-19 on the efforts of GOTV mobilizers. It also has some limitations. The data were collected exclusively from individuals and organizations engaged in voter mobilization. Although the experience of voters was relayed, it was provided through the perspective of the mobilizers. This study was conducted in St. Louis City and St. Louis County. The findings may not be generalizable to the entire state of Missouri or the USA as each county is allowed some flexibility on how to adhere to state law.

\section{Declarations}

Conflict of Interest The authors declare no competing interests.

\section{References}

Abramson, P. R., \& Aldrich, J. H. (1982). The decline of electoral participation in America. American Political Science Review, 76(3), 502-521. https://doi.org/10.1017/S0003055400188379

Allen, H. L., \& Sommers, B. D. (2020). Medicaid and COVID-19: At the center of both health and economic crises. JAMA, 324(2), 135-136. https://doi.org/10.1001/jama.2020.10553

Al-Rasheed, M. (2020). Protective Behavior against COVID-19 among the Public in Kuwait: An examination of the protection motivation theory, trust in government, and sociodemographic factors. Social Work in Public Health, 35(7), 546-556. https://doi.org/10.1080/19371918.2020.1806171

American Women, et al. v. State of Missouri No. 20AC-CC00333 (Circuit Court of Cole County 2020). https://electionlawblog.org/wp-content/uploads/MO-American-Women-20201022-decision. pdf

Anderson, C. J., \& LoTempio, A. J. (2002). Winning, losing and political trust in America. British Journal of Political Science, 32(2), 335-351.

Anderson, M. R. (2010). Community psychology, political efficacy, and trust. Political Psychology, 31(1), 59-84. JSTOR.

Associated Press. (2020, March). Stay-at-home order to start next week in St. Louis, KC. US News \& World Report. https://www.usnews.com/news/best-states/missouri/articles/2020-0321/stay-at-home-order-to-start-monday-in-st-louis

Barbot, O. (2020). George Floyd and our collective moral injury. American Journal of Public Health, 110(9), 1253. http://dx.doi.org.libproxy.wustl.edu/10.2105/AJPH.2020.305850

Barrie, C. (2020). Searching racism after George Floyd. Socius: Sociological Research for a Dynamic World, 6. http://dx.doi.org.libproxy.wustl.edu/10.1177/2378023120971507 
Bassett, M. T., Chen, J. T., \& Krieger, N. (2020). Variation in racial/ethnic disparities in COVID19 mortality by age in the United States: A cross-sectional study. PLOS Medicine, 17(10), e1003402. https://doi.org/10.1371/journal.pmed.1003402

Beaumont, E. (2010). Political agency and empowerment: Pathways for developing a sense of political efficacy in young adults. In Handbook of research on civic engagement in youth (pp. 525-558). John Wiley \& Sons Inc. https://doi.org/10.1002/9780470767603.ch20

Bhopal, S. S., \& Bhopal, R. (2020). Sex differential in COVID-19 mortality varies markedly by age. Lancet (london, England), 396(10250), 532-533. https://doi.org/10.1016/S0140-6736(20) 31748-7

Brady, H. E., \& McNulty, J. E. (2011). Turning out to vote: The costs of finding and getting to the polling place. The American Political Science Review, 105(1), 115-134. http://dx.doi.org.libproxy. wustl.edu/10.1017/S0003055410000596

Cooper, L. A., \& Williams, D. R. (2020). Excess deaths from COVID-19, community bereavement, and restorative justice for communities of color. JAMA, 324(15), 1491-1492. https://doi.org/10. 1001/jama.2020.19567

Craig, S. C. (1979). Efficacy, trust, and political behavior: An attempt to resolve a lingering conceptual dilemma. American Politics Quarterly, 7(2), 225-239. https://doi.org/10.1177/1532673X7900700207

Davey, M. (2017, December 20). Amid mourning for Michael Brown, call for change. The New York Times. https://www.nytimes.com/2014/08/26/us/michael-brown-funeral.html

Day, P. J., \& Schiele, J. (2012). A new history of social welfare (7 edition). Pearson.

Ellis, A. R. (2008). The cost of the vote: Poll taxes, voter identification laws, and the price of democracy. Denver University Law Review, 86(4), 1023-1068.

Erikson, R. S. (2015). Income inequality and policy responsiveness. Annual Review of Political Science, 18(1), 11-29. https://doi.org/10.1146/annurev-polisci-020614-094706

Ferguson Commission. (n.d.). Forward through Ferguson. Forward Through Ferguson. Retrieved January 26, 2019, from https://forwardthroughferguson.org

Floyd, D. L., Prentice-Dunn, S., \& Rogers, R. W. (2000). A meta-analysis of research on protection motivation theory. Journal of Applied Social Psychology, 30(2), 407-429. https://doi.org/10. 1111/j.1559-1816.2000.tb02323.x

Fortuna, L. R. (2020). Inequity and the disproportionate impact of COVID-19 on communities of color in the United States: The need for a trauma-informed social justice response. Psychological Trauma: Theory, Research, Practice, and Policy, 12(5), 443. https://doi.org/10.1037/tra0000889

Gaffney, A., Himmelstein, D. U., \& Woolhandler, S. (2020). COVID-19 and US Health financing: Perils and possibilities. International Journal of Health Services, 50(4), 396-407. https://doi. org/10.1177/0020731420931431

Garza, A. (2020). St. Louis Metropolitan Pandemic Task Force [BJC Healthcare]. St. Louis Metropolitan Pandemic Task Force Officials provide an update on COVID-19 in the area. https://www.bjc. org/Keeping-You-Safe/News/ArtMID/5837/ArticleID/4427/St-Louis-Metropolitan-PandemicTask-Force-officials-provide-an-update-on-COVID-19-in-the-area

Gee, G. C., \& Ford, C. L. (2011). Structural racism and health inequities. Du Bois Review : Social Science Research on Race, 8(1), 115-132. https://doi.org/10.1017/S1742058X11000130

Gentles, S. J., Charles, C., Ploeg, J., \& McKibbon, K. A. (2015). Sampling in qualitative research: Insights from an overview of the methods literature. The Qualitative Report, 20(11), 1772-1789.

Gollust, S. E., \& Rahn, W. M. (2015). The bodies politic: Chronic health conditions and voter turnout in the 2008 election. Journal of Health Politics, Policy and Law, 40(6), 1115-1155. https://doi. org/10.1215/03616878-3424450

Gray, L. M., Wong-Wylie, G., Rempel, G. R., \& Cook, K. (2020). Expanding qualitative research interviewing strategies: Zoom video communications. The Qualitative Report, 25(5), 1292-1301.

Gruber, J., \& Sommers, B. D. (2020). Paying for Medicaid-State budgets and the case for expansion in the time of coronavirus. New England Journal of Medicine, 382(24), 2280-2282. https://doi. org/10.1056/NEJMp2007124

Guest, G., Bunce, A., \& Johnson, L. (2006). How many interviews are enough?: An experiment with data saturation and variability. Field Methods, 18(1), 59-82. https://doi.org/10.1177/1525822X05279903

Hacker, J. S., \& Pierson, P. (2010). Winner-take-aall politics: Public policy, political organization, and the precipitous rise of top incomes in the United States. Politics \& Society, 38(2), 152-204. https://doi. org/10.1177/0032329210365042 
Hennink, M. M., Kaiser, B. N., \& Marconi, V. C. (2017). Code saturation versus meaning saturation: How many interviews are enough? Qualitative Health Research, 27(4), 591-608. https://doi.org/10. $1177 / 1049732316665344$

Hsieh, Y., Chen, Y. -L., \& Wang, Y. -C. (2021). Government and social trust vs. hotel response efficacy: A protection motivation perspective on hotel stay intention during the COVID-19 pandemic. International Journal of Hospitality Management, 97, 102991. https://doi.org/10.1016/j.ijhm.2021. 102991

Huang, K., Kemper, L., McBride, T. D., \& Maddox, K. E. J. (2020). Effects of Medicaid expansion on coverage, access, outcomes, and costs: Implications for Missouri. Center for Health Economics and Policy, 6.

Hudson, D., Sacks, T. A., Sewell, W., Holland, D., \& Gordon, J. (2020). Surviving the white space: Perspectives on how middle-class Black men navigate cultural racism. Ethnic and Racial Studies, 1, 19. https://doi.org/10.1080/01419870.2020.1834594

Jung, N., Kim, Y., \& de Zúñiga, H. G. (2011). The mediating role of knowledge and efficacy in the effects of communication on political participation. Mass Communication and Society, 14(4), 407-430. https://doi.org/10.1080/15205436.2010.496135

Kallio, H., Pietilä, A. -M., Johnson, M., \& Kangasniemi, M. (2016). Systematic methodological review: Developing a framework for a qualitative semi-structured interview guide. Journal of Advanced Nursing, 72(12), 2954-2965. https://doi.org/10.1111/jan.13031

Karp, J. A., \& Banducci, S. A. (2008). Political efficacy and participation in twenty-seven democracies: How electoral systems shape political behaviour. British Journal of Political Science, 38(2), 311334. http://dx.doi.org.libproxy.wustl.edu/10.1017/S0007123408000161

Keyssar, A. (2009). The right to vote: The contested history of democracy in the United States. Basic Books.

Kolb, S. M. (2012). Grounded theory and the constant comparative method: Valid research strategies for educators. Journal of Emerging Trends in Educational Research and Policy Studies, 3(1), 83-86. https://doi.org/10.10520/EJC135409

Lin, Y. -J., Yen, C. -F., Chang, Y. -P., \& Wang, P. -W. (2021). Comparisons of motivation to receive COVID-19 vaccination and related factors between frontline physicians and nurses and the public in Taiwan: Applying the extended protection motivation theory. Vaccines, 9(5), 528. https://doi.org/10. 3390/vaccines 9050528

Majette, G. R. (2003). Access to health care: What a difference shades of color make. Annals of Health Law, 12(1), 121-142.

van Manen, M. (2016). Phenomenology of practice: Meaning-giving methods in phenomenological research and writing. Routledge. https://doi.org/10.4324/9781315422657

Mattila, M., Söderlund, P., Wass, H., \& Rapeli, L. (2013). Healthy voting: The effect of self-reported health on turnout in 30 countries. Electoral Studies, 32(4), 886-891. https://doi.org/10.1016/j.electstud. 2013.07.010

McDonnell, J. (2019). Municipality size, political efficacy and political participation: A systematic review. Local Government Studies. https://doi.org/10.1080/03003930.2019.1600510

Milne, S., Sheeran, P., \& Orbell, S. (2000). Prediction and intervention in health-related behavior: A meta-analytic review of protection motivation theory. Journal of Applied Social Psychology, 30(1), 106-143. https://doi.org/10.1111/j.1559-1816.2000.tb02308.x

Missouri State Conference of the National Association for the Advancement of Colored People, et al. v. State of Missouri No SC98744 (Supreme Court of Missouri 2020). https://www.courts.mo.gov/file/ SC/Opinion_SC98744.pdf

Morrell, M. E. (2005). Deliberation, democratic decision-making and internal political efficacy. Political Behavior, 27(1), 49-69. https://doi.org/10.1007/s11109-005-3076-7

Morris, K., \& Miller, P. (2020). Voting in a pandemic: COVID-19 and primary turnout in Milwaukee, Wisconsin (SSRN Scholarly Paper ID 3634058). Social Science Research Network. https://doi.org/ 10.2139/ssrn.3634058

Niemi, R. G., Craig, S. C., \& Mattei, F. (1991). Measuring internal political efficacy in the 1988 national election study. The American Political Science Review, 85(4), 1407-1413. https://doi.org/10.2307/1963953

Oriola, T. B., \& Knight, W. A. (2020). COVID-19, George Floyd and human security. African Security, 13(2), 111-115. https://doi.org/10.1080/19392206.2020.1783760

Pacheco, J., \& Fletcher, J. (2015). Incorporating health into studies of political behavior: Evidence for turnout and partisanship. Political Research Quarterly, 68(1), 104-116. https://doi.org/10.1177/ 1065912914563548

Palinkas, L. A., Horwitz, S. M., Green, C. A., Wisdom, J. P., Duan, N., \& Hoagwood, K. (2015). Purposeful sampling for qualitative data collection and analysis in mixed method implementation 
research. Administration and Policy in Mental Health and Mental Health Services Research, 42(5), 533-544. https://doi.org/10.1007/s10488-013-0528-y

Pangborn, N., \& Rea, C. (2020). Race, gender, and new essential workers during COVID-19. Political Economy. https://digitalcommons.wcl.american.edu/wlpeconomy/2

Pollock, P. H. (1983). The participatory consequences of internal and external political efficacy: A research note. Western Political Quarterly, 36(3), 400-409. https://doi.org/10.1177/106591298303600306

Public Health Orders. (n.d.). COVID-19 information site. Retrieved January 18, 2021, from https://www. stlcorona.com/dr-pages-messages/public-health-orders/

Rather, R. A. (2021). Demystifying the effects of perceived risk and fear on customer engagement, cocreation and revisit intention during COVID-19: A protection motivation theory approach. Journal of Destination Marketing \& Management, 20, 100564. https://doi.org/10.1016/j.jdmm.2021.100564

Reichert, F. (2016). How internal political efficacy translates political knowledge into political participation. Europe's Journal of Psychology, 12(2), 221-241. https://doi.org/10.5964/ejop.v12i2.1095

Rosenstone, S. J., \& Hansen, J. M. (1993). Mobilization, participation, and democracy in America. Macmillan Publishing Company.

Schwartz, G. L., \& Jahn, J. L. (2020). Mapping fatal police violence across U.S. metropolitan areas: Overall rates and racial/ethnic inequities, 2013-2017. PLOS One, 15(6), e0229686. https://doi.org/ 10.1371/journal.pone.0229686

The Constitution of the United States: A transcription. (2015). National Archives. https://www.archives. gov/founding-docs/constitution-transcript

Lancet, T. (2020). The plight of essential workers during the COVID-19 pandemic. Lancet (london, England), 395(10237), 1587. https://doi.org/10.1016/S0140-6736(20)31200-9

Valentine, R., Valentine, D., \& Valentine, J. L. (2020). Relationship of George Floyd protests to increases in COVID-19 cases using event study methodology. Journal of Public Health, 42(4), 696-697. https://doi.org/10.1093/pubmed/fdaa127

Wong, L. (2008). Data analysis in qualitative research: A brief guide to using Nvivo. Malaysian Family Physician : THe Official Journal of the Academy of Family Physicians of Malaysia, 3(1), 14-20.

Youn, S., Lee, J. E., \& Ha-Brookshire, J. (2021). Fashion consumers' channel switching behavior during the COVID-19: Protection motivation theory in the extended planned behavior framework. Clothing and Textiles Research Journal, 39(2), 139-156. https://doi.org/10.1177/0887302X20986521

Publisher's Note Springer Nature remains neutral with regard to jurisdictional claims in published maps and institutional affiliations. 